\title{
Determinants of Banks' Capital Structure: A Review of Theoretical and Selected Empirical Research
}

\author{
Tengku Wasimah Raja Harun \\ Nazrol Kamil Mustaffa Kamil \\ Razali Haron \\ Zulkufly Ramly \\ Kuliyyah of Economics and Management Sciences \\ International Islamic University Malaysia \\ P.O. Box 10, 50728 Kuala Lumpur \\ Malaysia
}

\begin{abstract}
The determinant of capital structure is very crucial in decision making as the determinants of capital structure in banking system are vary from non-financial firms since banks played different roles from others. Banks are required to hold more capital than the minimum capital requirement laid down by the regulators. This is because of banks tend to confront with several risks which might be affected the banking operation and severely have possibility to insolvent. Nevertheless, there is limited studies investigate the determinants of banks' capital structure as this type of research were mostly conducted for non-financial firms. For banks, which considered as highly leverage, should have ability to determine the appropriate amount of capital to engross unpredicted losses arising from its daily transactions. Furthermore, the understanding on how bank choose their capital structure and the appropriate related theory still under-explored in the literature of banking. Therefore, due to some argument related to the theories, this paper is aiming to discuss on the capital structure from banking perspectives and explored the specific determinants which can be the ultimate factors to determine banks' capital structure.
\end{abstract}

Keywords - Capital structure, determinants, banks, theories

\section{Introduction}

The banking sector has played an important role in facilitating economic transformation and economic growth through various phases of economic development and implementation. Globally, ten years after the global financial crisis which was occurred in year 2007/2008, the banking industry seems to regain its health and have a good standing in the market. However, it should be noted that the banking sector is a very risky business and it deals with various types of risks. In this sense, until most recently, the issue of risks has been a subject that received much attention in the banking literature since the mid of 1980's. The banking sector is quite breakable institution in which are assembled based on the character or reputation, customers' trust and above all perilous leverage. In this circumstance, banks might face with failure if something happened badly due to unable to manage the shock waves right through the economy (Rajadhyaksha, 2004).

Since banks are considered as one of the risky business entities, it seems to see that banks have been always concerned with two most important issues such as liquidity and solvency (Amidu, 2007). This is due to nature of the banks itself where the bank acts as one of the institutions that provides liquidity in terms of capital over the demand of depositors through current accounts. In addition, banks need to extend credit through loan disbursement and liquidity to borrowers. This shows that the function of the bank is very different from non-financial firms where firms usually receive capital from banks to support the financial generation of a company such as buying assets or obtaining facilities to improve performance in order to sustain in the market (Kashyap et al., 1999). Accordingly, the success of a bank depends on the extent to which the bank can manage the capital structure to reduce the risks that are being experienced or in the future more effectively and efficiently.

As for example, looking to the history of Japan's banking crisis in 1991 until 2005, many of the commercial bank had confront with financial difficulties and there is also a small commercial bank went into liquidation even though the bank was insured by the deposit insurance system provided by the government. The causes of the crisis occurred due to the several reasons; 1) the loan disburse by bank were exceed the banks' limit specifically in risky loan portfolios without enough supervision and weak regulation during the crisis period, 2) decreasing amount of banks' capital base, and 3) increase in non-performing loans (NPL) due to the economic downturn and devaluation in price (Fuji \& Kawai, 2010). This shows that the ability of banks to manage the capital structure was inefficient added with the weak supervision and regulation by the authorities. 
In this sense, banks should make effective strategies to address the problem as stated, for instance determining how much capital is needed to overcome the risk in their daily operation. Otherwise, profits earned by banks also should be considered in assisting and mitigating the risks involved (Amidu, 2007).

Significantly, the above-mentioned issues have a decisive impact on the overall banks' capital structure. It can be seen that the excellent management on the capital structure become significant in which the banks not only obtain higher profitability but at the same time it can improve the stability and reduce the impact of risks since the capital structure might engages with the combination of debt and equity specifically appeared in the banks' balance sheet (Grais \& Kulathunga, 2006; Sakti et al., 2017). Due to this, banks should concern more to formulating their implementation on capital structure practices. Furthermore, the capital structure theory itself, namely, MM theory explained that the market value of firms is entirely autonomous towards the capital structure (Modigliani \& Miller, 1958). This is due to the existence of perfect capital market as well as the non-existence of corporate income tax which led to the capital structure remain constant (Sakti et al., 2017).

The discussion on the capital structure has gained great attention among the scholars, practitioners as well as regulators since the seminal work of Modigliani-Miller (1958) which introduced the irrelevant prepositions regarding to the firm's capital structure. However, the tremendous literature on capital structure which can be found in various sources such as books, journal articles, proceeding papers and any other sources has mainly focusing on the perspective of non-financial firm's despite of banking point of view in terms of identifying its determinants, analysing performance, governance etc. It can be found in Titman and Wessels (1988); Rajan and Zingales (1995); Bevan and Danbolt (2001); Hall et al. (2004); Hasan and Butt (2009); Frank and Goyal (2009); Khrawish and Khraiwesh (2010); San and Heng (2011); Awan et al. (2011); Ahmadpour et al. (2012); Salim and Yadav (2012); Ajanthan (2013); Dawar (2014); Chang et al. (2014); Rouf (2015); Guner (2016) and so forth.

To the best of researcher's knowledge, the research on capital structure specifically conducted for banks is, however, relatively limited compared to the non-financial firms in which there is few significant understandings on how banks practice its capital structure and what is the determinants or factors that might affect the decision on the capital structure made. Some studies related to banks' capital structure can be found in Kuo and Lee (2003); Asarkaya and Ozcan (2007); Kleff and Weber (2008); Amidu (2007); Gropp and Heider (2010); Octavia and Brown (2010); Juca et al. (2012); Shahchera (2013); Al-Mutairi and Naser (2015).As such, this study attempts to shed light on the importance of banks' capital structure by reviewing at the previous literature to address the gaps in the capital structure practices.

This paper is organized as follows: Section 2 discuss on the general concept of capital structure practices; Section 3 provides an overview on the existing capital structure theories; Section 4 present the critical review on theories related to banking perspectives; Section 5 carried out the empirical studies on determinants of capital structure and, finally, Section 6 concludes the paper and provides suggestions for further exploration.

\section{General concept of capital structure from banking perspectives}

The term "capital" become a vital and critical resources for all firms either financial or non-financial institutions. It can be divided into two main categories, namely; debt and equity. Debt can be classified as a contractual obligation where the firms borrow some amount of money from other institutions and need to repay it back within a stipulated period including with the amount of interest as agreed during the agreement was performed. Meanwhile, equity derived from the selling some of the firms' ownership or assets to raise fund for supporting the firms' operation and investment activities.

There are many definitions of capital structure derived from the previous literature. For instance, Keown et al. (1985) defined capital structure as the combination of the financial resources such as debt and equity which are listed in the balance sheets of the companies or institutions. In addition, Haugen and Senbet (1988) had defined capital structure as an option given to the firms to choose either internal or external financial instruments. Meanwhile, Schlosser (1989) defined capital structure as the proportion of debt to the total of capital of the firms. Brealey and Myers (1991) defined capital structure as a mixture of debt, equity or hybrid securities which issued by the firms. Furthermore, capital structure also can be referred as the total debt to total asset at book value in which can give effect to the profitability and riskiness of the firm (Bos \& Fetherston, 1993).

As there are many definitions given by the previous researchers, Gitman and Zutter (2012) had simplified the definition of capital structure where it can be referred as 'the mixture of debt and equity maintained by the firm'. In other words, when a company or institution decides to expand its operation or market, it needs some sort of capital and this may be in the form of debt or equity. Generally, making ineffective decisions about capital structure can cause firms to face financial problems and eventually bankruptcy. The firm's management establishes capital structure to maximize the value of firms (Alipour et al., 2015). 
However, in banks' point of view, banks are naturally highly leveraged as compared to the non-financial firms. When discussing about banking, it cannot run from carried out the issue of leverage as banks are highly leverage institutions compared to the non-financial firms and highly regulated sector in the economy (Ingves, 2014). That is why the high leverage possess by banks is closely related to what makes banks special than other industries. This is due to the fact that the liabilities of banks are commonly come from the deposits made by depositors in which it can be withdraw by depositors anytime they want. This kind of deposit commonly known as demand deposit. In contrast, non-financial firms do not engage with any deposit matter as the firms by its nature providing money to be deposited into banks. Meanwhile, other types of liabilities held by banks are the asset-backed securities which act as the collateral in making a financial transaction such as disbursing loan portfolios. This justification is making sense to the above assumption where the banks seems to be more leverage compared to other industries (Berlin, 2011).

Meanwhile, the asset side of the banks' balance sheet (see Table 1) seems to be riskier as compared to the liabilities side. This is because, loans represent as one of the important transactions of a bank's assets followed by investments portfolio. Even though banks engaging with diversified of loans portfolio which seems to be less risky compared to any single loan, the banks must closely surveillance and monitor the loans wisely in order to ensure the returns from the loan are sufficient to cover the demand from depositors as well as any other creditors (Berlin, 2011).

Table 1: Prototype of Bank's Balance Sheet

\begin{tabular}{l|l}
\hline Assets & Liabilities \\
\hline Loans and advances to customers & Customers' deposits \\
Cash and cash balance with other banks & Due to banks and other financial institutions \\
Investment in associates, subsidiaries and joint & Other liabilities \\
ventures & Equity and reserves \\
Financial assets held for trading & Sundry creditors \\
Cash and cash balances with Central Banks & \\
\hline
\end{tabular}

Source: Adopted from Greuning and Iqbal (2008)

However, Berlin (2011) argued that the common laws of corporate finance do not seem applicable to the banks where the main caused is due to the deposits hold by banks are insured. In this case, the uninsured sources of fund such as equity seems to be quite expensive. This circumstance had made most banks so reluctant to deal with equity and much prefer on debt transaction. As the capital structure itself indicate the mixture between debt and equity, banks are much rely on debt as form of financing since banks assume debt is more secure and cheaper compared to equity (Juks, 2010). It can be illustrated through the transaction of buying a house, where the customer will request loan from bank and the customer's debt is backed by the house. Therefore, in the event of default by the borrower, the house which act as collateral will be taken off to repay back the default made. That is why banks prefer debt as they feel that they are being protected.

Furthermore, the reason of choosing debt rather than equity because of the interest rates on debt are normally lower compared to the required returns on equity (Juks, 2010). For example, banks basically take deposits and bonds and then will turn them into financing or investment. These transactions involved fixed interest rate as well as unrestricted commitment to pay back at a certain stipulated period. However, bankers argue that engaging in equity investment will impose them to bear higher cost such as the cost of monitoring in which equity seems to be risky and requires higher rate of return (Snyder, 2010). This argument supported by Juks (2010) where the equity holders demand for a higher rate of return due to the condition of the investment itself is considered as risky compared to debt investment. Moreover, banking industry believed that when they are engaging with expensive equity in which will incur higher cost to them, this automatically will give impact to the borrowers as well as the bank might transfer the cost to the borrowers. In this circumstance, the banks might worry as it can affected their profitability as they believed that increased in equity requirements will affect to the decrease in the return on equity of banks (Snyder, 2010).

Nevertheless, some researcher argues that equity is not expensive and not entirely will burden the banks to incur higher costs. Admati et al. (2013) argued that equity is not expensive at all and bank also are not required to have high leverage to perform the entire transactions such as lending, accepting deposits and issuing money for securities. However, they did not dispute hardly if banks prefer to choose debt financing over equity as banks can obtain tax benefits and have implicit assurances by the authorities. In this case, it seems to see that the authorities had reprimand equity financing as the debt financing being subsidize. Yet, this circumstance cannot be a reason to keep on allowing the banks to proceed perilous high leverage level. Therefore, Admati et al. (2013) suggests that the regulators play a vital role in controlling the equity pay-out and issuance as it can help banks to increase equity capital efficiently and offer with additional funds which applicable for lending activities. As such, higher equity requirement supported with taxes can be a great technique to secure fund (Admati et al., 2013). 
Despite of concerning on the issue of debt and equity, it should bear in mind that the banks' capital structure also related to the certain regulatory requirement. Considerably, banks have an identical and unique criterion of being able to issue federally insured debt and at the same time, banks also bear the cost of capital which including the threat of being placed in dissolution of which is likely to eliminate the shareholders' investment (Harding et al., 2013).Banks are regulated under the supervision of the Basel Accord (1988) which imposed binding capital requirements in 1990 (Berlin, 2011). As derived from Berlin (2011) in his writing, the aims of the Basel Accord were to; 1) increase the capital level for most banks; 2) increase the global consistency in capital standard regulations; 3) modify the capital requirements in order to enhanced well reflect to the definite credit risk; and 4) impose the capital requirements for some off-balance-sheet exposures.

The Basel Committee on Banking Supervision mentioned that the Basel Accord are voluntary regulatory standards on bank capital adequacy, stress testing and market liquidity risk (Melicher, 2016). Therefore, as a measure to overcome the weakness in the financial regulation stemming from the financial crisis occurred in year 2007/2008 ago, the Basel III was introduced in 2013 where it aims to increase the capacity and efficiency of the banking sector to overcome the impact of the financial stress and economic downturn. Basel III also can improve risk management and governance and strengthen the transparency and disclosure of banks in making daily transactions (Berlin, 2011). In this sense, the banks need to comply with the capital adequacy and requirement stated by the Basel Committee to strengthen their capital structure and can survive even during the economic downturn and financial crisis in the current and future onwards.

\section{An overview of existing capital structure theories}

The capital structure literature has advanced significantly since the seminal paper by Modigliani and Miller (1958) become a foundation for the later theories that exist in today's corporate finance study and for various research determinants of capital structure specifically. The preliminary study of capital structure that proposed by Modigliani and Miller (1958) shows how capital structure or leverage is not relevant in the firms' value. In addition, they also argue that the optimal capital structure does not exist in a perfect market where they assumed that there is no cost and transaction taxes included. These assumptions had resulted that the composition of debt and equity do not give any impact to the cost of capital, cash flow and value of the firms (Sanusi, 2002).

Since Modigliani and Miller (MM) theory seems to be a bit controversial among corporate finance scholars, there are subsequent works had been carried out to reduce some constraint of the MM irrelevance theorem in which the later theories might involve discussion on taxes, asymmetric information, bankruptcy cost and so forth. Initially, the trade-off theory model was originated from the debate over the Modigliani and Miller theorem where this theory suggests optimum capital structure is the exchange of debt benefits such as interest tax shields and debt costs like financial distress and agency costs (Brigham \& Houston, 2004). Myers (1984) stated that there might be a controversial issue regarding how valuable the tax shields are, and which cost of financial embarrassment are material. These disparities give only variation on a theme where the firm is supposed to substitute debt for equity or vice versa, until the value of the firms is maximized (Myers, 1984). This level of debt is the optimum level which maximises the value of the firm. After this point, the bankruptcy cost become more than the tax shield, and this indicates a decrease in the value of the firm for further debt. This is called as the trade-off theory of capital structure (Brealey et al., 2011).

However, the trade-off theory did not deliberate the issue of information asymmetry. This issue was later introduced by pecking order theory which was first proposed by Donaldson in year 1961 and this theory was modified by Myers and Majluf in year 1984. This theory states that firms choose to finance investments through retained earnings instead of utilizing external funds, despite the size of the company. In this case, the debt will be repaid if the accumulated income exceeds the investment requirement. Otherwise, in the case of external funds required, external equity will be the last priority required by the firm (Donaldson, 1961). According to the trade-off theory, firms balance between the benefits of tax shield of debt and costs of financial distress, when making capital structure decision. In this sense, the cost of agency is often included in trade-off consideration (Gambacorta \& Marqus-Ibanez, 2011).

Meanwhile, another theory that carried out the concept of asymmetric information is known as signalling theory which was introduced by Ross (1977). This theory is developed based on the view that the firm's capital structure can signal the firm's information to investors outside the firm. This theory assumed that the owner/manager of the firm know the exact state or have full information regarding the firm compared to the outsiders or investors. For instance, investors look at the level of outstanding debt owned by the firm is a good thing because of their high levels of debt shows that the firm has a very high quality. However, from the point of view of the owner/manager of the firm, they prefer equity relative to debt. This is due to the use of excessive debt can cause managers to lose their jobs if the firm suffered heavy losses or go insolvency. 
Another theory that has been well-discussed in firms' capital structure is agency theory where this theory indicates that financing with risky debt could lead to an agency problem and the optimal capital structure can be achieved through minimising the costs incur from the conflicts among the stakeholders of the firm (Jensen \& Meckling, 1976). This theory had identified two types of conflicts such as (1) conflict between shareholders and managers and (2) conflict between shareholders and debt-holders. Nevertheless, Grossman and Hart (1982) argued that the utilization of debt can reduce the agency cost through increasing the chances of being bankruptcy and providing a managerial discipline.

Harris and Raviv (1991) stated that the problem of agency cost of equity occurs when managers are encouraged to invest in risky businesses for shareholders' interests as they are not the sole recipients to get any outcome from the firm. In this situation, the lender may incur costs in the event of an investment failure as members of the limited liability entity have limited liability for business debt. According to Jensen (1986), debt plays an important role in observing or minimizing conflict between shareholders and firm managers. In this sense, the manager's free cash flow may decrease due to additional debt issues since the firm is now focusing on the provision of debt.

Later theory regards to the capital structure is market timing theory which was introduced by Baker and Wurgler (2002). This theory suggests that the firm issue shares when the stock price is perceived to be high (overvalued) and will repurchase their shares when the price is low (undervalued). Baker and Wurgler (2002) provide proof that the equity market timing has a tenacious outcome towards firms' capital structure. They further define the market timing measure such as weighted average of external capital needs over the past several years where in this sense, the weight used is known as market to book values of the firm. As a result, they found that the changes of the debt are strong and positive relationship with market timing measure. Therefore, they conclude that there is no optimal capital structure in market timing theory, nevertheless the capital structure only evolves as the cumulative effect of past attempts to time the equity market timing strategies (Luigi \& Sorin, 2009; Shahar, et al., 2015).

\section{Critical review of the existing theories on bank's capital structure}

Bank is one of the unique industries as compared to the non-financial firms which have a special characteristic and roles that need to be taken into consideration when studying their capital structure. Basically, the literature on capital structure is usually alienated between banks and non-financial firms. This is because of their uniqueness in which their business operations and practices are quite different to the non-financial firms where it relates to some imposition of regulation and supervision by the government or the central bank such as the regulation on the minimum capital ratio. Furthermore, in its operation, banks much prefer on leverage as compare to the equity level as compared to the non-financial firms since leverage is much cheaper than equity.

There are some arguments in modern corporate finance literature regarding to the capital structure related to banks. The arguments are concern on two main sights which vary in their forecast of the cost of equity and the cost of debt when the bank is levered (Al-Deehani et al., 1999). Based on the classical approach, it is suggested that when debt is increased, the cost of equity or debt will suffer a modest change as well as the financial risk seems to be insignificant. As a result, it will reduce the weighted average cost of capital of banks' and at the same time will increase the bank's market value (Al-Deehani et al., 1999).

In addition, Merton $H$. Miller, the pioneer of $M \& M$ Propositions was asked to discuss about whether that propositions can be apply to banks or not in 1995 . He acknowledged that the irrelevance of the propositions to banking sector tend to be more clearly by looking to different angle of the capital structure equation in which focusing more on the equity side rather than liability side. Furthermore, he argued that many previous researches in the last 30 years has been precisely withdrawals from the stringent assumptions of the propositions such as the issue of taxes and cost of agency (Miller, 1995). He further argues that the view of banks' equity capital being limited and costly is incoherent, and in the circumstance if the capital market is left to its expedients, the propositions cannot be ruled out even in the presence of agency and imperfection information.

Berger, Herring and Szego (1995) in their writing about the role of capital in financial institutions have empowered the capital structure of the financial institution to be determined by the same withdrawal from the perfect world of M \& M propositions that define the structure of non-financial firm capital. In these circumstances, the market imperfections they consider determining the capital structure of the optimum financial institutions such as taxes, cost of financial distress, transaction costs, signal behaviour as well as agency problems arising from asymmetric information between shareholders and creditors and between owners and managers (Berger et al., 1995). However, it should be noted that the banks are quite different from non-financial firms in terms of two important aspects such as: (1) the existence of a regulatory safety net that protects the security and goodness of the bank and the possibility of lowering the bank's capital, and (2) to increase the bank's capital (Berger et al., 1995; Miller, 1995). Therefore, since banks hold higher leverage in nature as compared to the non-financial firms, it seems to see that this is not parallel with the implications of M\&M Propositions where these propositions expect the capital structure to differ arbitrarily across the firms (Berger et al., 1995). 
This is supported through current literature found in DeAngelo and Stulz (2014) which argued that the MM theorem is not suitable to be used for banking research as it can lead to some issues. In this case, MM model did not consider the important concept of capital structure specifically related to the banking field. As noted, banks might engage with large amount of deposit-related intermediation, liquidity premium on deposits and so forth. Due to this, banks are categorized as high leverage institution where the combination of leverage and low asset risk appears as the best base expected from banks before introducing taxes, moral hazards, or other deviation factors. Meanwhile, it is different to the non-financial firms where these firms basically engaging with producing goods and services as well as create value via actual project selections where it is not suitable to support secure debt since its normally involved cash flow uncertainty. In contrast, banks engaged with risk management to develop asset structure that help to support their daily operation especially liquid claims. Due to this, DeAngelo and Stulz (2014) stressed that MM theorem is inappropriate to support the capital structure for banks.

To overcome the issue, the capital structure theories were established specifically for banks which pioneered by Douglas W. Diamond and Raghuram G. Rajan in year 2000. They wrote on a theory of bank capital in which they build a model for capital structure in which focusing on the cost of reducing liquidity and the credit flow. Basically, banks can generate liquidity due to its deposits are delicate and inclined to runs. Furthermore, in the circumstance that uncertainty increased, this will make the deposits extremely delicate in which case there is a role for outside bank capital (Diamond \& Rajan, 2000). Increased in bank capital would result decrease in liquidity in which facilitates the banks to sustain in the industry and at the same time, banks can avoid the financial distress. Diamond and Rajan (2000) also mentioned that the optimal capital structure for bank will trade off the effects of bank capital specifically on the creation of liquidity, the cost of distress faced by banks, and the ease of forcing repayment from the debtors.

In addition, Diamond and Rajan (2000) also take into consideration regarding to the policies of regulatory capital requirements and deposit insurance. These two elements were not merely discussed in the non-financial firms since these firm is quite differing to banks in which banks are regulated under Basel Accord specifically when involved with capital and banks would engage with deposits. Gorton and Pennacchi (1990) also agreed that bank's roles and assets are not similar to the non-financial firms and banks also do not suffer from the cost of asymmetric information. Meanwhile, Slovik and Cournede (2011) provide an evidence from the literature that capital structure of banks is dominantly determined by the regulatory capital requirement and not related to the standard capital structure determinants as what engaged with the non-financial firms.

In 2011, Allen, Carletti and Marquez had discussed about the excess capital that banks hold and how it is anticipated to support the market discipline and stability of the system. They developed a model of capital which is parallel to the observation that banks may prefer a level of capital which is above the minimum amount regulated (Allen et al., 2011). Their model is based on the idea that when banks operate in a perfectly competitive loan market, this circumstance could attract the borrowers to apply the loan and at the same time bank prefer to use costly capital instead of increase interest on loans. Later on, Allen et al. (2015) had developed an equilibrium general capital structure model which include the bankruptcy costs, deposit and equity market. In their analysis, they had provided two key assumptions of their model in which the deposit and equity market are segmented and there will be a bankruptcy costs for banks.

Swai et al. (2016) stated that what makes bank become special compared to the non-financial firm is since banks much hold high leverage. Bank liabilities are converted into assets and in some circumstance, the liability also can be in the form of collateral such as time deposit. And this are the outcomes of the banking transactions or activities (Swai et al., 2016). From the non-financial firm perspectives, it does not engage much with the liability since they prefer equity and at the same time, they do not engage with the deposit but become a depositor to the banks. The authority had regulated the bank that banks should maintain the capital requirement at variety level of risk and if the banks do not comply with the regulation stated, banks will be charged to penalties, and this can lead to liquidation. Therefore, in this circumstance, banks need to maintain the capital ratios to look better to the eyes of regulators and enhance banking stability to mitigate risks.

\section{Existing studies of capital structure determinants}

Although there are numerous of publication on capital structure in the form of journal articles, books, conference papers and reports has increased tremendously, literature on the capital structure specification for banks is quite limited as compared to non-financial firms. This occurred since most researches had omitted financial firms to be studied as banks are subjected with certain regulation stipulated by the authorities. In the context of firms, several studies have investigated its determinants and the most cited and referred papers regarding to firms' capital structure are derived from Frank and Goyal (2009). Based on this previous study, the researchers had carried out some important factors that can define the capital structure model, namely, profitability, tangibility, asset size and growth opportunities. 
Table 2 summarize the forecast of trade-off theory and pecking order theory to justify the relationship between firm's leverage and its determinants. These factors have been applied widely among the later researchers in determining the firm's capital structure.

Table 2: The testing result of the capital structure theories

\begin{tabular}{l|l|l}
\hline Determinants & Trade-off theory & Pecking order theory \\
\hline Profitability & + & - \\
Tangibility & + & - \\
Asset size & + & - \\
Growth opportunities & - & $+/-$ \\
\hline
\end{tabular}

Source: Adapted from Frank \& Goyal (2009)

Notes: A “+” and "- "sign indicates the direction of relationship between the variable and firm's leverage

Meanwhile, in banking point of view, there is quite limited study on the determinants of bank capital structure since much studies focusing on firm's perspective. For example, Amidu (2007) indicate a negative relationship between leverage and profitability in which this study is consistent with previous study by Titman and Wessels (1988) in which it confirms with the prediction by pecking order theory. Banks with higher profitability basically can increase the level of internal financing rather than external financing. The negative association between leverage and profitability is reliable with pecking order theory but unreliable with the trade-off theory. The trade-off theory states that many profitable firms should hold more debt than firms with little profit. Firms with little profit expected to face very high bankruptcy costs and obtain interest tax shields that are less valuable as compared to the profitable firms. However, pecking order theory insists that firms are more likely to choose internal finance than external sources of funding. This can help firms reduce the need for debt financing (Frank \& Goyal, 2009). The negative association between leverage and profitability also can be found in Octavia and Brown (2010); Gropp and Heider (2010); Caglayan and Sak (2010); Toumi et al. (2015) and so forth.

In other determinants of capital structure such as size, there is no definite findings in the previous literature as several studies found indicated a positive association between size and leverage (Rajan \& Zingales, 1995; Frank \& Goyal, 2009; Gropp \& Heider, 2010; Octavia \& Brown, 2010). The static trade-off theory forecast the large firms tend to have more debt compared to small firms since large firms are seems to be more diversified and have less possibility of default risk. Furthermore, the large firms usually have a standing in debt markets and due to this, the chances of these firm confronting with cost of agency is lower. Therefore, the static trade-off theory assumed that relationship between capital structure and size should be positive. In contrast, pecking order theory argues an inverse relationship between these determinants because this theory clarify that the large firms normally established for a long time and already being known in the marketplace. Due to this, the large firms might confront with lower adverse selection as compared to small firms. Concerning the effect of size on the bank's leverage, Gropp and Heider (2010) and Octavia and Brown (2010) have clarify the result where larger banks tend to have more leverage and this finding support the static trade-off theory.

Gropp and Heider (2010) also found that tangibility of asset might influence the leverage of banks. The authors claimed that increase in tangible assets might be beneficial especially in the case of financial distress in which the relationship support the trade-off theory. Furthermore, the existence of tangibility as a part of capital structure determinant can give strain to the shareholders to use instead of high-risk assets to low risk assets (Frank \& Goyal, 2005). In this sense, the tangible assets that bank hold such as land, buildings, inventory and current assets can give guarantee to the banks for the money that banks already disburse to the debtors and can boost the amount of debt in the capital structure (Kamran et al., 2014). However, the pecking order theory indicated a negative relationship between leverage and tangibility due to the limited information asymmetry related to tangible assets which makes equity seems to have lower cost (Harris \& Raviv, 1991). In addition, some previous study revealed that the effects of the tangibility towards the banks' leverage is not significant as the increase of tangible assets hold by banks might providing more collateral to back up in the event of liquidation, thus can increase more leverage spontaneously (Toumi et al., 2015). Accordingly, the effect of tangibility towards bank's leverage need to be discover in depth due to the mixing result and argument among the theories.

Meanwhile, concerning the effect of growth opportunities on leverage, the trade-off theory and some agency theories expects a negative relationship between these variables (Frank \& Goyal, 2005). Based on firms' perspective, growth firms seem to decrease in its value during financial distress. This can be illustrated through the issue of underinvestment in which it can give severe impact towards growing firms and lead them to have less debt. However, the pecking order theory argues a contradict finding where the growth opportunities and leverage are positively related. This due to the assumption where firms that hold much investment have a possibility to accrue debt over time. 
In the context of banking, some studies revealed a positive association between leverage and growth since the banks are deficient of internal funds to finance its investment prospects, and due to this, banks need an external fund to cover its insufficiency (Al-Mutairi \& Naser, 2015). Furthermore, banks that have a better growth have better chances to acquire funds without difficulty due to its reputation and high diversification which can imposed them to alleged lower level of risk.

It is worth pointing out that the similarities or differences between financial and non-financial firms are always become an interesting topic in the literature of finance especially on capital structure. Much studies have been investigated the determinants on capital structure among non-financial firms as these studies became a benchmark for the academician to study in the perspective of banking. Therefore, Table 3 provides a summary from selected previous studies pertinent to the determinants of capital structure in the scope of banking.

Table 3: Determinants of capital structure used from selected studies

\begin{tabular}{|c|c|c|c|c|c|c|c|c|c|c|}
\hline \multirow{2}{*}{ Authors } & \multicolumn{9}{|c|}{ Explanatory variables used $* *$} & \multirow[t]{2}{*}{ Other variables used } \\
\hline & LE & LI & $\mathrm{S}$ & $\mathrm{P}$ & $\mathrm{C}$ & $\mathrm{R}$ & $\mathrm{T}$ & $\mathrm{G}$ & $\mathrm{D}$ & \\
\hline $\begin{array}{l}\text { Gropp and } \\
\text { Heider (2010) }\end{array}$ & l & I & l & I & I & I & I & I & l & $\begin{array}{ll}\text { - } & \text { Market-to-book ratio } \\
\text { - } & \text { Deposit insurance }\end{array}$ \\
\hline $\begin{array}{c}\text { Octavia and } \\
\text { Brown (2010) }\end{array}$ & l & - & I & I & I & - & - & - & I & - $\quad$ Market-to-book ratio \\
\hline Juca et al. (2012) & I & - & l & I & - & l & - & I & l & $\begin{array}{ll}\text { - } & \text { Market value of deposit } \\
\text { - } & \text { Market value of non- } \\
\text { deposit } \\
\text { - } & \text { Guarantees } \\
\text { - } & \text { Compensation program }\end{array}$ \\
\hline $\begin{array}{l}\text { Shahchera } \\
\text { (2013) }\end{array}$ & I & I & I & I & - & I & - & - & - & $\begin{array}{ll}\text { - } & \text { Regulation } \\
\text { - } & \text { Business cycle } \\
\text { - } & \text { Deposit/asset ratio } \\
\text { - } & \text { Intermediation rate }\end{array}$ \\
\hline $\begin{array}{l}\text { Al-Mutairi and } \\
\text { Naser (2015) }\end{array}$ & I & l & I & I & - & I & I & - & - & $\begin{array}{ll}\text { - } & \text { Age of bank } \\
\text { - } & \text { Asset growth }\end{array}$ \\
\hline
\end{tabular}

Source: Compiled by author

Notes: ** Leverage (LE), Liquidity (LI), Bank Size (S), Profitability (P), Collateral (C), Risk (R), Tangibility (T), Growth $(G)$, Dividend $(D)$

\section{Conclusion and the way forward}

Selected works on capital structure determinants in banking perspective has been thoroughly reviewed and discussed in this study. Via appropriate review, the selected works was further categorized into two parts of discussions, namely, theoretical and empirical. The theoretical works on capital structure have been categorized into three main groups:

1. general concept of capital structure from banking perspectives

2. an overview of existing capital structure theories

3. critical review of the existing theories on bank's capital structure

Meanwhile, the empirical works on capital structure has been discussed on the determinants of capital structure from the banking outlooks as the main aims of this paper is to discuss on the determinants used to investigate banks' capital structure. Currently, there is quite limited empirical research and analytical tools can be found on capital structure and the financing decision specifically for banks. In contrast, tremendous research on capital structure can be found in the literature either in terms of theoretical or empirical works on non-financial firms as it became a benchmark among researchers to reviewed. Unlike non-financial firms, research on capital structure in banking is still scarce and not comprehensive since most of the literature has omitted the banking industry to be a part of unit of analysis or sample in many researches. This is because bank is one of the regulated bodies and it basically being supported by the regulators or government. In addition, banks need to take into consideration regarding to the regulatory requirement in making a capital structure decision. That is why many aforementioned studies had put aside the banking industry.

Regarding to the theory of capital structure, most of the theories discussed seems to be not applicable for banking field. If applicable, the theories need to be modified or need to look at the different angle. This is because; banks are required to maintain a minimum capital ratio stipulated by the regulators and rating agencies. In addition, banks also engaged with deposits which make it different to the non-financial firms. 
Due to this, banks have propensity or possibility to exchange capital with debt to increase its profitability in terms of return on capital as well as uplift investors' satisfaction. However, this condition is against to the MM irrelevant theorem. The argument that banks can enhance its profitability through exchange capital with debt is not the outcome of neglecting the effect of risk on leverage.

Therefore, from the above discussion, there are some suggestions carried out by the authors. Since there is quite limited empirical research on capital structure in banking fields either conventional or Islamic banks, this can give opportunities for future research to conduct more studies on capital structure that involve both banking systems. As the operation of Islamic banks quite different to the conventional banks, it will become more interesting to compare these two banking systems in terms of decision making towards their capital structure. Furthermore, the previous studies showed that there are no decisive conclusions made in order to determine the specific determinants of banks' capital structure as some studies argued that the determinants are just similar to the non-financial firms. Finally, the paper proposes that both regulators and banking players should concern on the determinants of capital structure to ensure the soundness, stability, performance and competitiveness in order to survive in the market.

\section{References}

Admati, A. R., DeMarzo, P. M., Hellwig, M. F., \& Pfleiderer, P. (2013). Fallacies, Irrelevant Facts and Myths in the Discussion of Capital Regulation: Why Bank Equity is not Socially Expensive. Stanford University Graduate School of Business Research Paper No. 13-7, 1-77.

Ahmadpour, A., Samimi, A. J., \& Golmohammadi, H. (2012). Corporate Governance and Capital Structure: Evidence from Tehran Stock Exchange. Middle-East Journal of Scientific Research 11 (4), 531-535.

Ajanthan, A. (2013). Impact of Corporate Governance Practices on Firm Capital Structure and Profitability: A Study of Selected Hotels and Restaurant Companies in Sri Lanka. Research Journal of Finance and Accounting, Vol.4, No.10, 115-126.

Al-Deehani, T., Karim, R. A., \& Murinde, V. (1999). The Capital Structure of Islamic Banks Under the Contractual Obligation of Profit Sharing. International Journal of Theoretical and Applied Finance, Vol. 2, No. 3, 243-283.

Alipour, M., Mohammadi, M. F., \& Derakhshan, H. (2015). Determinants of Capital Structure: An Empirical Study of Firms in Iran. International Journal of Law and Management, Vol. 57, Issue 1, 53-83.

Al-Kayed, L. T., Zain, S. R., \& Duasa, J. (2014). The Relationship Between Capital Structure and Performance of Islamic Banks. Journal of Islamic Accounting and Business Research, Vol. 5, No. 2, 158-181.

Allen, F., Carletti, E., \& Marquez, R. (2011). Credit Market Competition and Capital Regulation. The Review of Financial Studies, Vol. 24, No. 4, 983-1018.

Allen, F., Carletti, E., Goldstein, I., \& Leonello, A. (2015). Moral Hazard and Government Guarantees in the Banking Industry. Journal of Financial Regulation, Vol. 1, Issue 1, 30-50.

Al-Mutairi, A., \& Naser, K. (2015). Determinants of Capital Structure of Banking Sector in GCC: An Empirical Investigation. Asian Economic and Financial Review, 959-972.

Amidu, M. (2007). Determinants of Capital Structure of Banks in Ghana: An Empirical Approach. Baltic Journal of Management, Vol. 2, Issue 1, 67-79.

Asarkaya, Y., \& Ozcan, S. (2007). Determinants of Capital Structure in Financial Institutions: The Case of Turkey. Journal of BRSA Banking and Financial Market, Vol. 1, Issue 1, 91-109.

Awan, H. M., Bukahri, K. S., \& Ansari, R. M. (2010). Corporate Governance Practices and Their Impact on Firm's Capital Structure and Performance: Case of Pakistani Textile Sector. Proceedings 8th AFC samos2011, Vol. 1, 390-400.

Baker, M., \& Wurgler, J. (2002). Market Timing and Capital Structure. Journal of Finance, Vol. LVII, No. 1, 132.

Berger, A. N., Herring, R. J., \& Szego, G. P. (1995). The Role of Capital in Financial Institutions. Journal of Banking \& Finance, Vol. 19, 393-430.

Berlin, M. (2011). Can We Explain Banks Capital Structure? Business Review Q2, 1-11.

Berlin, M. (2011). Can We Explain Banks' Capital Structures? Business Review, Q2, 1-11.

Bevan, A. A., \& Danbolt, J. (2002). Capital Structure and its Determinants in the United Kingdom - A Decompositional Analysis. Applied Financial Economics 12(3), 159-170.

Bos, T. and Fetherston, T.A. (1993). Capital Structure Practices on the Specific Firm. Research in International Business and Finance, Vol. 10, 53-66.

Brealey, R. A., \& Myers, S. C. (1991). Principles of Corporate Finance, 4th Edition. New York: McGraw-Hill.

Brealey, R. A., Myers, S. C., \& Allen, F. (2011). Principles of Corporate Finance: 10th Edition. New York: McGraw-Hill Irwin.

Brigham, E. F., \& Houston, J. F. (2004). Fundamentals of Financial Management. Thomson/South-Western.

Butt, S. A., \& Hasan, A. (2009). Impact of Ownership Structure and Corporate Governance on Capital Structure of Pakistani Listed Companies. International Journal of Business \& Management, Vol. 4, No. 2, 1-8. 
Çağlayan, E., \& Şak, N. (2010). The Determinants of Capital Structure: Evidence from the Turkish Banks. Journal of Money, Investment and Banking, Issue 15, 57-65.

Chang, C., Chen, X., \& Liao, G. (2014). What are the Reliably Important Determinants of Capital Structure in China? Pasific-Basin Finance Journal, Vol. 30, 87-113.

Dawar, V. (2014). Agency Theory, Capital Structure and Firm Performance: Some Indian Evidence. Managerial Finance, Vol. 40, Issue 12, 1190-1206.

DeAngelo, H., \& Stulz, R. M. (2014). Liquid-claim Production, Risk Management and Bank Capital Structure: Why High Leverage is Optimal for Banks. Fisher College of Business Working Paper Series Dice Centre WP 2013-8, 1-45.

Diamond, D. W., \& Rajan, R. G. (2000). A Theory of Bank Capital. The Journal of Finance, 55(6), 2431-2465.

Diamond, D. W., \& Rajan, R. G. (2000). A Theory of Bank Capital. The Journal of Finance, Vol. 55, No. 6, 24312465.

Donaldson, G. (1961). Corporate Debt Capacity: A Study of Corporate Debt Policy and the Determination of Corporate Debt Capacity. Boston: Beard Books.

Donaldson, G. (1961). Corporate Debt Capacity: A Study of Corporate Debt Policy and the Determination of Corporate Debt Capacity. Boston: Beard Books.

Frank, M. Z., \& Goyal, V. K. (2005). Trade-off and Pecking Order Theories of Debt. In Handbook of Corporate Finance: Empirical Corporate Finance. Handbooks in Finance Series, Elsevier/North-Holland.

Frank, M. Z., \& Goyal, V. K. (2009). Capital Structure Decisions: Which Factors are Reliably Important? Financial Management, Vol. 38, Issue 1, 1-37.

Fujii, M., \& Kawai, M. (2010). Lessons from Japan's Banking Crisis 1991 - 2005. Asian Development Bank Institute (ADBI) Working Paper 222, (pp. 1-19). Tokyo.

Gambacorta, L., \& Marques-Ibanez, D. (2011). The Bank Lending Channel: Lesson from the Crisis. Basel, Switzerland: Monetary and Economic Department, Bank for International Settlements.

Gambacorta, L., \& Marqus-Ibanez, D. (2011). The Bank Lending Channel: Lessons from Crisis. Bank for International Settlement Working Papers No 345, 1-36.

Gitman, L. J., \& Zutter, C. J. (2012). Principles of Managerial Finance, 13th Edition. Boston: Pearson Prentice Hall.

Gorton, G. B., \& Pennacchi, G. G. (1990). Financial Intermediaries and Liquidity Creation. The Journal of Finance, Vol. 45, Issue 1, 49-71.

Grais, W., \& Kulathunga, A. (2006). Capital Structure and Risk in Islamic Financial Services. Islamic Finance: The Regulatory Challenge, 69-93.

Greuning, H. v., \& Iqbal, Z. (2008). Risk Analysis for Islamic Banks. Washington, D.C.: The International Bank for Reconstruction and Development/The World Bank.

Gropp, R., \& Heider, F. (587-622). The Determinants of Bank Capital Structure. Review of Finance, Vol. 14, Issue 4, 2010.

Grossman, S. J., \& Hart, O. D. (1982). Corporate Financial Structure and Managerial Incentives. In J. J. McCall, The Economics of Information and Uncertainty (pp. 107-141). Chicago: University of Chicago Press.

Guner, A. (2016). The Determinants of Capital Structure Decisions: New Evidence from Turkish Companies. Procedia Economics and Finance 38, 84-89.

Hall, G. C., Hutchinson, P. J., \& Michaelas, N. (2004). Determinants of the Capital Structures of European SMEs. Journal of Business Finance \& Accounting, Vol. 31, No. 5-6, 711-728.

Harding, J. P., Liang, X., \& Ross, S. L. (2007). The Optimal Capital Structure of Banks: Balancing Deposit Insurance, Capital Requirements and Tax-Advantage Debt. Economic Working Papers, Department of Economics, University of Connecticut, 1-47.

Harris, M., \& Raviv, A. (1991). The Theory of Capital Structure. The Journal of Finance, Vol. XLVI, No. 1, 297355.

Haugen, R. A., \& Senbet, L. W. (1988). Bankruptcy and Agency Costs: Their Significance to the Theory of Optimal Capital Structure. Journal of Financial and Quantitative Analysis, Vol. 23, Issue 1, 27-38.

Ingves, S. (2014). Banking on Leverage. Auckland, New Zealand: Basel Committee on Banking Supervision, Bank for International Settlements.

Jensen, M. C. (1986). Agency Costs of Free Cash Flow, Corporate Finance, and Takeovers. The American Economic Review, Vol. 76, No. 2, 323-329.

Jensen, M. C., \& Meckling, W. H. (1976). Theory of the Firm: Managerial Behavior, Agency Costs and Ownership Structure. Journal of Financial Economics, Vol. 3, No. 4, 305-360.

Jucá, M. N., Sousa, A. F., \& Fishlow, A. (2012). Capital Structure Determinant's of North American Banks and the Compensation Executive Program-An Empiric Study on the Actual Systemic Crisis. International Journal of Business and Management, Vol. 7, No. 17, 13-26.

Juks, R. (2010). Why Banks Prefer Leverage? Sveriges Riksbank Economic Review, 23-36. 
Kamran, H. W., Khan, M. U., \& Sharif, S. (2014). Capital Structure Determinants: Evidence from Banking Sector of Pakistan. Research Journal of Finance and Accounting, Vol. 5, No. 19, 59-67.

Kashyap, A. K., Rajan, R., \& Stein, J. C. (2002). Banks as Liquidity Providers: An Exploration for the Coexistence of Lending and Deposit Taking. The Journal of Finance, Vol. LVII, No. 1, 33-73.

Keown, A. J., Martin, J. D., \& Petty, J. W. (1985). Basic Financial Management, 3rd Edition. New Jersey: Prentice Hall International Editions.

Khrawish, H. A., \& Khraiwesh, A. H. (2010). The Determinants of the Capital Structure: Evidence from Jordanian Industrial Companies. JKAU: Econ. \& Adm., Vol. 24 No. 1, 173-196.

Kleff, V., \& Weber, M. (2008). How Do Banks Determine Capital? Evidence from Germany. German Economic Review, Vol. 9, Issue 3, 354-372.

Kuo, H.-C., \& Lee, C.-H. (2003). The Determinants of the Capital Structure of Commercial Banks in Taiwan. International Journal of Management, Vol. 20, No. 4, 515-522.

Melicher, R. W. (2016). Introduction to Finance, Markets, Investments, and Financial Management. Cram101 Textbook Reviews.

Miller, M. H. (1995). Do the M\&M Propositions Apply to Banks? Journal of Banking \& Finance, Vol. 19, 483489.

Modigliani, F., \& Miller, M. H. (1958). The Cost of Capital, Corporation Finance and the Theory of Investment. The American Economic Review, Vol. 48, No. 3, 261-297.

Myers, S. C. (1984). The Capital Structure Puzzle. The Journal of Finance, Vol. 39, No. 3, 575-592.

Myers, S. C., \& Majluf, N. S. (1984). Corporate Financing and Investment Decisions When Firms Have Information That Investors Do Not Have. Journal of Financial Economics, 187-221.

Octavia, M., \& Brown, R. (2010). Determinants of Bank Capital Structure in Developing Countries: Regulatory Capital Requirement versus the Standard Determinants of Capital Structure. Journal of Emerging Market, Vol. 15, Issue 1, 50-62.

Rajadhyaksha, N. (2004). The Rise of Financial Conglomerates. Business World, 28-33.

Rajan, R. G., \& Zingales, L. (1995). What Do We Know about Capital Structure? Some Evidence from International Data. The Journal of Finance, Vol. 50, No. 5, 1421-1460.

Ross, S. A. (1977). The Determination of Financial Structure: The Incentive-Signalling Approach. The Bell Journal of Economics, Vol. 8, No. 1, 23-40.

Rouf, M. A. (2015). Capital Structure and Firm Performance of Listed Non-Financial Companies in Bangladesh. The International Journal of Applied Economics and Finance 9 (1), 25-32.

Sakti, M. R., Tareq, M. A., Saiti, B., \& Akhtar, T. (2017). Capital Structure of Islamic Banks: A Critical Review of Theoretical and Empirical Research. Qualitative Research in Financial Markets, Vol. 9, Issue 3, 292308.

Salim, M., \& Yadav, R. (2012). Capital Structure and Firm Performance: Evidence from Malaysian Listed Companies. Procedia - Social and Behavioural Sciences 65, 156-166.

San, O. T., \& Heng, T. B. (2011). Capital Structure and Corporate Performance of Malaysian Construction Sector. International Journal of Humanities and Social Science, Vol. 1, No. 2, 28-36.

Sanusi, N. A. (2002). Bukti Empirik Kajian Struktur Modal. Jurnal Ekonomi Malaysia, 39-67.

Schlosser, M. (1989). Corporate Finance: A Model-Building Approach. Hertfordshire: Prentice Hall.

Shahchera, M. (2013). The Determinants of Banks' Capital Structure: The Case of Iran. Journal of Money and Economy, Vol. 8, No. 1, 141-167.

Slovik, P., \& Cournede, B. (2011). Macroeconomic Impact of Basel III. OECD Economic Department Working Papers No. 844. Paris: OECD Publishing.

Snyder, B. (2010). Why Bank Equity is Not Expensive. Insights: Accounting, Finance of Stanford Graduate School of Business.

Swai, T. A., Lwiza, D. V., \& Ndanshau, M. O. (2016). Determinants of Bank Capital Structure - Does Bank Ownership Matter? Evidence from Tanzania. Business Management Review, Vol. 19, No. 1, 1-12.

Titman, S., \& Wessels, R. (1988). The Determinants of Capital Structure Choice. The Journal of Finance, Vol. 43, No. 1, 1-19.

Toumi, K., Viviani, J.-L., \& Louhichi, W. (2015). Alternative Financial Decision Principles: Theoretical Foundations of Islamic Banks' Capital Structure. Recent Developments in Alternative Finance: Empirical Assessments and Economic Implications, Vol. 22, 157-172. 